\title{
Muslim Religiosity and Purchase Intention of Different Categories of Islamic Financial products
}

\begin{abstract}
Considering the rapid growth of Islamic Financial Products (IFPs) worldwide and the limited research on Muslims' buying behaviour of such products, this research examines the relationship between religiosity, consumer buying attitude and purchase intention towards different categories of IFPs. The findings suggest that buying attitude has full mediation for deposit, credit and capital market products and partial mediation for insurance products on the association between Muslim religiosity and their purchase intention. Interestingly, religiosity influenced positively even for insurance and capital market products. This is in contrast with our hypothesised relationships for capital and insurance products. The study contributes to the literature by enhancing our understanding of the complex mediating religiosity - buying attitude - purchase intention relationships for different categories of IFPs.
\end{abstract}

Keywords: Religion, Muslim religiosity, Islamic finance, Consumer behaviour

\section{Please cite this article as}

Newaz, F. T., Fam, K.-S., \& Sharma, R. R. (2016). Muslim religiosity and purchase intention of different categories of islamic financial products. Journal of Financial Services Marketing, 21(2), 141-152. doi:10.1057/fsm.2016.7 


\section{INTRODUCTION}

Religion has been considered a taboo subject and too sensitive to be submitted for investigation because of the potential for inadvertent offence and the legal protection afforded freedom of religion. In addition, religion is everywhere in our lives and therefore may have been overlooked by researchers as an obvious variable for investigation in the field (Sun, Goh \& Fam, 2009). "Religious revival" as one of the ten megatrends that appeared in the new millennium (Arnould et al., 2004) has transformed this situation and has triggered the motivation to gain a better understanding of the impact of religion on consumer behaviour (Razzaque \& Chaudhry, 2013).

Religiosity is an individual's level of commitment to a particular religious group (Fam, (Waller \& Erdogan, 2004) Religiosity, rather than religion, plays a dominant and influential role in attitude formation and is related to questions around why people consume (Razzaque \& Chaudhry, 2013). Individual differences in religiosity are also related to established differences in perception that may guide the individual in the process of selecting solutions for a particular need (La Barbera, 1987). As religiosity has significant influence on consumers' behaviour, a better understanding of religiosity and consumers' buying behaviour relationships is likely to allow the development of more effective strategies for different religious or national markets (Essoo \& Dibb, 2004; Bobokhonov \& Brito, 2015).

While a number of marketing and consumer research specifically identified the important effects that religion can have on cross-cultural marketing decisions, the concept of religiosity in the context of Islam remains limited (Shukor \& Jamal, 2013). The growth in the number of Muslims worldwide has intensified many researchers' interest in gaining a better understanding of Islam and Muslim consumers' behaviour (Porter \& Schwab, 2009). In an Islamic country, Shariah provides criteria for judgement on every aspect of a Muslim's individual and social life. In spite of the criteria, some controversies exist around the 
consumption of halal (permitted in Islam) and haram (not permitted in Islam) goods and services (Youssef, et al., 2011; Mukhtar \& Butt, 2012). Shariah also deals with financial services relating to interest, non-halal investments, and speculation. Marketers cannot violate these Islamic principles when providing financial service and distributing interest (riba).

The significance of this study lies in its focus on the Islamic financial industry and on purchase intention of different categories of Islamic financial products (IFPs). Past studies on the relationship between religiosity and consumer behaviour have been limited only to Islamic financial products such as Islamic banking. This study will examine religiosity and whether differences in the level of religious beliefs influence Bangladeshi Muslim consumers' buying attitudes and purchase intentions towards different categories of Islamic financial products. Specifically, the findings of this study may assist Islamic finance practitioners' to identify potential consumers and segmenting the target market based on religiosity and IFP category to increase their businesses worldwide. Having a complete picture of such relationships, and therefore an understanding of the impact of religiosity on buying behaviour in a Muslim-majority democratic country context, is also expected to provide insights for academics and managers.

\section{LITERATURE REVIEW AND CONCEPTUAL MODEL}

\section{Islamic Banking and Finance}

The Islamic banking objectives, procedural and operational characteristics are dissimilar to the conventional banking. Hussein (2010) claims that these differences have impact on capital, liquidity, risk, and consumer's behaviour towards confidence. In general, the Islamic banking system operation is based on four main methods: moudaraba (trust financing), mousharaka (benefits and loss sharing), mourabaha (cost-plus financing), and ijara (leasing) 
(Rani, 2015). An Islamic bank is essentially an intermediary and a trustee of the depositors' money. As a depositor, the customer 'invests' in the bank's activities and then share the profits or losses resulting from the investment shares. In Islamic banking, there should be no reward without taking a risk (Masry, Debes \& Baradie, 2015; Tamimi, Lafi \& Uddin, 2009). For the conventional banks, their assets were derived from the savings of customers, and the difference is that the conventional banks pay a rate of interest to the depositors and charge a rate of interest to the borrowers. Fundamentally, the difference between the two banking systems is the payment and levying of interest, and unlike conventional banks, Islamic banks are prohibited from undertaking or financing unethical/non-halal activities (Hussein, 2010).

Islamic finance is growing rapidly across the financial globe.

The core values that govern Islamic banking are shared risk and profit sharing between parties, the promise of fairness for all and that transactions are based upon real economic activities that do not involve interest, gambling, speculative trading, and non-halal activities. According to Asian Development Bank, Islamic finance has great potential to stimulate growth and alleviate poverty (ADB, 2015; Karbhari, Naser, \& Shahin, 2004). For instance, there was evidence that with Islamic banking consumers in Pakistan, Bangladesh and Philippines has better access to financial services. It has also encouraged savings among consumers who do not wish to open an account with conventional banks. There are risks associated with Islamic finance. Since all investment products must be Shariah-compliant, financial regulators tend to face challenging issues including liquidity, deposit insurance, and consumer protection (Aris et al., 2013). Moreover, because of the complexity of Shariahcompliant related matters, financial institutions habitually rely on the interpretation of the Shariah authority/board which, unfortunately, can differ between Shariah scholars. For instance, certain contractual terms deemed to be valid under Shariah by the scholars of one 
school may not be acceptable to scholars from another school. Such variations in interpretation could cause investors to lose confidence in the Shariah-compliant product and bank (Mejia et al., 2014).

\section{Regulations and Government Supports in Bangladesh}

Recognizing the challenges facing Islamic finance, several Governments have been proactive in developing new legal frameworks, financial regulations, and market infrastructure to better accommodate the segment. While some countries, such as Iran and Sudan, have established fully Shariah-compliant financial systems, others are becoming focal markets due to the growing market share of Islamic finance (IFSB, 2013). Bangladesh Bank, the country's central bank, is the main authority that regulates the Islamic banking industry. For the capital market activities, the Securities and Exchange Commission (SEC) has full regulatory mandate while the Insurance Development \& Regulatory Authority Bangladesh supervises the insurance and Takāful sectors (IFSB, 2015, Ahmad \& Hassan, 2007). In 2009, the Central Bank formulated a guideline for conducting Islamic banking business in the country whereby the Board of Directors of the respective banks is responsive in ensuring that the activities of their banks are Shariah-compliant. Moreover, independent Shariah Supervisory Committee with experienced and knowledgeable in Islamic Jurisprudence must be formed by the Board of Islamic banks and conventional commercial banks with Islamic windows. Although this industry has gained increased credibility and progress has been made, it has yet to develop a legal infrastructure and regulatory framework (Chowdhury, 2015; Chowdhury, 2015a, Ahmad \& Hassan, 2007).

\section{Religiosity-Consumer behaviour Model}

According to Essoo \& Dibb (2004), 'Religious affiliation or the adherence of individuals to a particular religious group has been termed as ascribed status (p. 686)'. This suggests that 
like race and nationality, religious affiliation has effect on individual life often predates birth, size of family, attainment of educational level, wealth accumulation, and the type of decisions one takes in life (Hirschman, 1983). Hirschman (1983) further claims that religious denominational affiliations might be viewed as cognitive systems. A cognitive system is a collection of beliefs, values, expectations and behaviours that are shared by members of a group or a society (Al-Hyari et al., 2012; Bobokhonov \& Brito, 2015).

To undertake this study, we proposed a Religiosity-Consumer Behaviour model. Primarily, this model advocates that Muslims' religiosity plays an influential role in consumers' buying behaviour (Rehman \& Shabbir, 2010; Soesilowati, 2010). Although there are few empirical studies in the literature regarding religiosity and the effect on buying decisions and the consumption process, there is an implicit belief that religiosity should positively affect purchase intention and provide tangible results (Delener, 1990) A review of the extant religiosity, consumer behaviour literature and Theory of Reasoned Action (TRA) has led to the choice of the key measure of this study. Measurement of the degree of religious commitment can provide a basis for a thorough and insightful prediction of consumers' buying behaviour.

According to Soesilowati (2010), Muslims' religiosity determines their intention to consume Shariah-compliant products. This study argues that Muslims' religiosity influences purchase intention towards IFPs directly and indirectly by influencing their attitude towards IFPs. However, we also claim that religiosity, consumers' buying attitude and purchase intention relationships are likely to vary for different IFPs. The proposed conceptual model is shown in Figure 1.

\footnotetext{
* INSERT FIGURE 1 ABOUT HERE*
} 


\section{Religiosity and purchase intention}

Religiosity is reflected through individual attitudes and behaviours, therefore the degree to which religion affects one's attitude and behaviour depends on the individual's level of religiosity and the importance one places on the religion itself (Sood \& Nasu, 1995). Highly religious individuals are likely to be more dogmatic and more conservative than less religious individuals. Thus, the more religious person is more likely to align their behaviour to their religious laws. Those who are strongly committed to religion are both attitudinally and behaviourally able to take decisions consistent with religion (Sood \& Nasu, 1995). Individual differences in religiosity are related to stable differences in perception that may guide the individual in the process of selecting solutions to a particular need (Gorsuch \& Smith, 1983).

Islamic society is affected by a distinct Islamic world view (three fundamental principles: unity, responsibility to the community, and justice) based on Shariah (Sulaiman, 2003). Therefore, religiosity impacts Muslim consumers' likes and dislikes (Rehman \& Shabbir, 2010) and they will consider buying the products if the products do not violate or contradict their sacred ideas (Yun, et al., 2008). Mukhtar and Butt (2012) claim religiosity is one of the prominent predictors of a better understanding of consumer intention to choose Shariahcompliant products. According to Hong \& Lee (2014), religious reasons are the principle motivations for Muslims to choose products that adhere to Islamic objectives and values. Previous studies have thoroughly documented the importance of religious factors affecting bank customers' attitudes and Islamic banking preferences (Dahari, et al., 2015; Metwally, 1996). This leads to the following hypothesis:

H1: The greater the degree of religiosity, the greater the purchase intention of Muslim individuals towards IFPs. 


\section{Mediating role of buying attitude}

Although religion mandates strict laws in terms of buying financial products, the extent to which its adherents follow those Shariah laws is likely to vary (Youssef et al., 2011) and this variation is affected by attitude (Ajzen, 1991). The extent to which Muslims will have a positive buying attitude towards IFPs depends on the individual's degree of religiosity (Soesilowati, 2010). Religion impacts devotees' beliefs and attitudes toward a particular element through its doctrines (Al-Hyari et al., 2012; Bobokhonov \& Brito, 2015). Religiosity also plays an important role in measuring consumers' attitudes to various questionable consumer practices (Vitell \& Paolillo, 2003). Religion is one of the most important factors in shaping the attitude of Islamic banking customers (Metwally, 1996) and plays a key role in influencing retail consumers' attitudes towards Islamic finance (Gait \& Worthington, 2008). Invariably, these authors' study accentuates that Muslim consumers choose Islamic financial products to conform to their religious beliefs. Thus, the following hypothesis is proposed:

H2. The greater the degree of religiosity, the greater the Muslim individual's favourable attitude towards IFPs.

Several studies have shown that the significant effect of attitude on intention (Ramayah \& Mohd, 2006) and that a behavioural intention reflects a person's decision to perform the behaviour (Ajzen, 1991). From a consumer behavioural aspect, a consumer's intention to purchase a product is built on a positive attitude towards a particular product. Such a positive attitude towards a product appears also to be affected negatively by attitude towards other products in the choice set (Laroche, et al., 1996). Previous pertinent studies observed that religion influences both peoples' attitudes and purchasing decisions (Essoo \& Dibb, 2004). Thus, the Islamic financial industry expects Muslims to view Islamic finance as relevant to the Muslim obligation (Loo, 2010). Preceding studies also supported the premise that a consumer's attitude is one of the significant determinants in influencing the intention to use 
Islamic personal financing (Amin, et al., 2010). It has also been observed that positive attitude or degree of favourableness towards Islamic financing is responsible for determining the intention to purchase Islamic personal financing products (Taib, et al., 2008). Accordingly, it is hypothesised that

H3: Muslim consumers with a more favourable attitude towards IFP have a higher purchase intention of IFPs.

Based on the arguments that consumers' buying attitude influences consumers' purchase intention (H3) and people's religiosity has an impact on their buying attitude (H2), it follows that the relationship between religiosity and purchase intention is mediated by consumers' buying attitude towards IFPs.

\section{Effects across Islamic financial product categories}

Hitherto, different categories of Islamic financial products (such as deposit products, credit products, capital market products and insurance products) have been offered in direct competition to the financial products offered by conventional banks, even in Muslim countries (Mamun, 2011). All these categories of IFP are principally compliant with the main tenets of Shariah law on interest, non-halal investments, and speculation (Gait \& Worthington, 2008; Gait \& Worthington, 2009). Despite a general recognition of the underlying Islamic principles, there is still doubt amongst the larger Muslim community as to what constitutes an IFP. Islamic finance still faces obstacles in its development and a lack of standard interpretations for each category of IFP (Sadiq \& Black, 2012), which may affect whether customers choose to buy a particular product or not.

Islamic deposit and credit products offered by Islamic banks are very similar to the products offered by conventional banks, except that Islamic financing principles apply to the underlying bank assets and liabilities (Gait and Worthington, 2008). For Islamic deposit and 
credit products, no transaction that involves interest in any form can be undertaken, such as simple or compound, low or high, institutional or individual (Yusof, 2008). Customers are generally aware of various common Islamic deposit and credit products offered by banks (Khan, et al., 2007) and there is a strong demand and preference for interest-free banking services from a segment of people who have a strong desire to abide by the rules and principles set by Shariah law (Mamun, 2011). Given these considerations, it is hypothesised that:

H4a: The higher the religiosity, the higher the purchase intention in favour of Islamic deposit products and credit products.

The significance of capital markets (interest bearing bonds and stocks) in the Islamic financial system also stems from the point that Islam forbids interest taking but inspires trade. Although capital market products usually comply with Shariah laws, consumers are less likely to invest in these products for two reasons (Ali, 2005). Firstly, capital market speculations are not accepted for economic and religious reasons (Warde, 2010). Secondly, even highly religious and knowledgeable people have less understanding and awareness of how money and investments are handled in Islam (Hassan \& Mahlknecht, 2011). At present, different individuals and financial entities, depending on their degree of awareness of Shariah-compliance, are voluntarily adopting or avoiding certain practices. Therefore, the investor base for Islamic capital market products is very small and sluggish (Ali, 2005).

The Shariah law also applies to Islamic insurance. However, Muslim consumers still have doubt regarding this insurance because the use of, and investment in, insurance companies is not permitted because 'safety' or 'insurance' is not itself viewed as an object of sale in classical Islamic jurisprudence. Thus, the insured-insurer relationship is regarded to be one affiliated to gambling, where the insured as buyer pays a periodic premium as price, but may or may not be given the object of sale (compensation in case of loss), conditional to chance. 
Another consideration that driven Islamic jurists to prohibit insurance is the fact that insurance companies tend to invest their assets in interest-based instruments, for instance government bonds and mortgage-backed securities (Ahmed, 2010). Considering the above issues, takaful branded schemes are specially developed to encompass the elements of shared responsibility, joint indemnity, common interest and solidarity, which are accepted by Shariah (Billah, 2007). Nevertheless, many Muslims around the world are still not convinced of the complete and unquestionable acceptability of insurance, especially life insurance or family takaful schemes (Siddiqui \& Athemy, 2008). In reality, the growth of takaful is far way behind its potential. The features, models and structures of takaful are unknown to Islamic consumers in general, whereas information regarding Islamic banking is increasingly being spread (Saaty \& Ansari, 2008). The above discussion leads to the following hypotheses:

H4b: The higher the religiosity, the less the purchase intention in favour of Islamic capital market and insurance product.

Gait and Worthington (2009) suggest that attitudes, perceptions and motivations towards Islamic methods of finance are the most important factors in determining the intention of purchasing Islamic methods of finance by retail consumers. Previous studies have identified Islamic principles as the key factors among Muslims for selecting Islamic financial products (Osman, et al., 2009). By strengthening Muslims' desire to follow Islamic tenets, Islamic financial institutions are encouraging them to financial transactions in a halal way (Loo, 2010). Hence,

H4c: Muslim consumers with favourable attitudes towards IFPs will have a higher purchase intention of all categories of IFPs. 
Based on arguments in $\mathrm{H} 4 \mathrm{a}-\mathrm{c}$, it is proposed that buying attitude will mediate the religiosity and purchase intention relationships for all the IFP categories

\section{METHODOLOGY}

The data for this study comes from a structured questionnaire through a field survey in Bangladesh. The development of the questionnaire was based on the conceptual model that helps to identify the required information and the relationship that needed to be investigated. This study distributed and collected 1,292 usable survey questionnaires from five public universities, 20 business organisations and five associations of retired employees in Bangladesh. AMOS (Analysis of Moment Structures), the programme for SEM data analysis is used in this study to analyse the data, validate the measurement model and test the hypotheses.

Religiosity is measured as a second order construct of all the five dimensions of religiosity, namely religious belief, practice, knowledge, experience and consequence. The construct measures the respondents' degree of religiosity. These dimensions are drawn from Ilyas (1992). Buying attitude scale items are adopted from (Gait \& Worthington, 2009). This measurement scale is designed in such a way as to elicit the relevant attributes of Islamic finance that could determine peoples' perception of IFPs. Purchase intention of IFPs is measured in terms of a person's plan to engage in some action within a specified period of time, and the probability that he or she will perform a buying behaviour. The scale items for this construct are drawn from Amin et al. (2010). An additional measurement item relating to information about the respondents' preferences for the different categories of IFPs (deposit products, borrowing products, capital market products and insurance products) is included in this study. All the used construct items are presented in Table 1.

*Table 1 about here* 


\section{RESULTS}

Before analysing the structural model, the measurement model was analysed. As shown in Table 1, all the factor loadings of the construct items load on the relevant constructs well and are significant at the $\mathrm{p}<.001$. The values of factor loading being more than .50 indicate convergent validity of the constructs. The alpha values range between .67 and .87 and thus are above the minimum threshold of .60 (Matzler \& Waiguny, 2005) and thus meet the construct reliability criteria. The discriminant validity was established by Average Variance Extracted (AVE) and Chi-square differential test. Moreover, both the first order and second order models were compared using AIC indices and the lower value of AIC for the second order model indicates a better fit as compared to the first order model. Overall, the measurement model meets the convergent and discriminant validity criteria. The structural model results are summarised in Table 2 . The model fit criteria including $\chi^{2 / \mathrm{df}}$, CFI, TLI, and RMSEA is reported and indicate that the model has a good fit.

\section{*Insert Table 2 about here*}

As shown in Table 2, Hypotheses 1, 2 and 3 are accepted: religiosity positively influences both buying attitude and purchase intention towards IFPs. The result also shows the significant positive effect of consumers' buying attitude on purchase intention, as stated in Hypothesis 3. As expected, these results show that consumers' buying attitude performs as a partial mediator in the relationship between religiosity and consumers' purchase intention towards IFPs.

In terms of product categories of IFPs, religiosity has a significant and positive influence on the purchase intention of Islamic deposit, credit and capital market products. Conversely, there is no direct significant influence of religiosity on the purchase intention of Islamic insurance. Considering the relationship between religiosity and purchase intention in terms of 
different product categories, Hypothesis $4 \mathrm{a}$ is accepted and Hypothesis $4 \mathrm{~b}$ is rejected. The impact of religiosity on insurance and capital market products is positive as against the negative hypothesised relationships. There is a positive relationship between buying attitude and purchase intention for all categories of IFPs, which is significant. Hence, Hypothesis H4c is accepted. Considering the positive influence of religiosity on the buying attitude towards IFPs, it is surprising that consumers' buying attitude fully mediates the relationship between religiosity and purchase intention towards Islamic insurance. However, consumers' buying attitude partially mediates this relationship for Islamic deposit, credit and capital market products.

\section{MANAGERIAL IMPLICATIONS}

The findings confirm that Muslim consumers' buying attitudes are positively influenced by their religiosity. That is, devout consumers place greater importance than less religious consumers on Shariah-compliant financial products. Findings from this study are consistent with previous studies that found religiosity has a significant influence on consumers' attitudes towards IFPs (Metwally, 1996; Ullah \& Lee, 2012). This finding also shows that individuals who are highly committed to their religion place considerable emphasis on product attributes when purchasing financial products. Religious doctrines often provide moral codes and values. Followers of these doctrines are obliged to observe them. Budiman (2012) claims that high religiosity inspires a consumer to find out more about the associated attributes of products. Consumer behaviour is generally based on the collective values and moral codes accepted within a particular society. For the more religious consumers, their behaviours are more likely to be shaped by their strong religious belief (Ashraf, Robson \& Sekhon, 2015). In the case of this study, it was found that religiosity relates significantly with Muslim consumers' view of Islamic law and their attitudes towards Shariah-compliant financial products. This result clearly contrasts with those of previous studies which established that 
religious drivers have little impetus for the use of Islamic finance. For instance, previous studies found that consumers placed more importance on the high profits and low service charges offered by conventional finance (Zaher \& Hassan, 2001). However, the findings from this study significantly identified that religiosity represents the primary predictor for increasing the probability of favourable attitudes towards IFPs among Muslim consumers in Bangladesh, rather than the associated features of the financial services, such as location of the bank, service charges, and high returns.

In addition, this study found that buying attitude significantly and positively impacts consumer buying intention towards IFPs. This result supports the view that religious people with favourable attitude are more interested to buy IFPs. Buying attitude forms as (a) belief and evaluations of attributes or characteristics, and (b) emotional feelings such as like or dislike, for IFPs (Kotler, et al., 2004). The finding underscores the importance of buying attitude as a key factor in convincing people to purchase IFPs. This result corroborates with previous findings, that is, consumer attitude is an important element in manipulating the intention to use Islamic finance (Amin et al., 2010). According to the Theory of Reasoned Action (TRA), a person's favourable buying attitude can add value to purchase intention and, through the correct influence of buying attitude, purchase intention can be enhanced. The consideration of customers' attitudes towards products has become more significant due to the influence of religiosity on consumers' buying attitudes. Therefore, IFP providers must not totally rely on religious factors as a strategy to secure customers' loyalties (Khan et al., 2007). Muslims who have a sound basic knowledge of Islam are familiar with the term 'Shariah'. Thus, this research indicates that by creating awareness of Shariah principles in Bangladesh, IFPs that satisfy the needs and preferences of Muslims will ensue, providing them with spiritual harmony while they consume the products. 
Despite the findings that religious people show more favourable purchase intention towards IFPs, religiosity alone has not always demonstrated positive results or a strong effect on purchase intention (Soesilowati, 2010). It has not been uniformly viewed as a valuable predictor of purchase decision (Dusuki \& Abdullah, 2007). However, through the partial mediating effect of buying attitude, the result indicates that religiosity can successfully influence purchase intention of IFPs, in general, in the presence of favourable consumer buying attitude. The implication is that neither religiosity nor consumer buying attitude is sufficient alone to persuade people to purchase IFPs; rather, the two working in tandem provide the greatest potential value in the buying decision process.

As expected, this study finds a significant direct and indirect positive influence of religiosity on purchase intention of Islamic deposit and credit products. The reasons religious Muslims prefer to be associated with the Islamic banking system is that Islamic banks are committed to the principle of Shariah and prohibit the receipt and payment of interest in any of their operations. Therefore, the demand for Islamic banking products is enormous (Yusoff, et al., 2008). An interpretation of this result is that the profit-and-loss sharing (PLS) arrangements distinguish Islamic banks from conventional banks, which reflects Islamic ideals in financial affairs, risk and equity in welfare distribution. The prohibition in dealings with interest payment encourages Muslim consumers to give up the certainty of investment returns in order to fulfil their religious commitments.

Religiosity showed direct positive (as against hypothesised negative relationship) and indirect positive influence on purchase intention of Islamic capital market products (interest bearing bonds and stocks). Islamic capital market products are treated as highly useful alternative investments for the diversification of portfolios, since these products are created according to Islamic principles (with special focus on social justice, ecology and kindness, to create investment products and financial markets that are both ethical and sustainable). This result 
supports earlier findings that Islamic capital market products have become increasingly popular with both Muslims in secular and democratic countries and non-Muslim investors (Hassan \& Mahlknecht, 2011).

For Islamic insurance products, this study did not find any direct significant relationship between religiosity and purchase intention of Islamic insurance products. The relationship turned out to be positive in contrast with the negative hypothesised relationship. Shariah law does not allow Muslims to purchase insurance products, particularly life insurance. According to the Islamic faith, life is given or taken away by God, and anyone buying an insurance policy is, in fact, going against God's will. For the insurance companies, the sales of insurance in Bangladesh or in Muslim majority countries, the approach is to gain the support of religious organizations. Unlike the previous studies which focused mainly on macroeconomics as a factor influencing the consumption of family takaful (Redzuan, et al., 2009), this study found that subjective norms, such as religious organisations, have significant influence on an individual's perception and acceptance of Islamic insurance. In general, the sale of insurance schemes among the Muslims continues to be an uphill battle for many companies. Many Muslims around the world are still not convinced of the complete and unquestionable permissibility of life insurance or family takaful schemes. For insurance products buying attitudes plays a greater role (full mediation) and thus even insurance products could be successfully marketed by creating awareness and influencing their attitude. This helps getting out of taboo relating to buying insurance products.

\section{LIMITATIONS AND FUTURE RESEARCH}

As our analysis is based on data from Bangladesh, similar tests with data from other countries should be a natural extension of the research. Another limitation of this study is that the majority of the respondents are male. Future research should include female respondents so as to produce a balanced representation of the population. A further limitation is that the data 
was collected using survey questionnaire. Religion is a personal matter. In order to have an in-depth picture of consumers' religious values and motivational factors, future study should include a qualitative aspect. Lastly, the current study examined four categories of IFPs. Further studies in this area could include additional product categories. 


\section{References}

Ahmad, A.U.F. and Hassan, M.K. (2007) Regulation and performance of Islamic banking in Bangladesh. Thunderbird International Business Review 49(2): 251-277.

Ahmed, A. (2010) Global financial crisis: An Islamic finance perspective. International Journal of Islamic and Middle Eastern Finance and Management 3(4): 306-320.

Ajzen, I. (1991) The theory of planned behaviour. Organizational Behaviour and Human Decision Processes 50(2): 179-211.

Al-Hyari, K., Alnsour, M., Al-Weshah, G. and Haffar, M. (2012) Religious beliefs and consumer behaviour: From loyalty to boycotts. Journal of Islamic Marketing 3(1): 155-174.

Ali, S.S. (2005) Islamic Capital Market Products: Developments and Challenges. Jeddah, Saudi Arabia: Islamic Development Bank: Islamic Research and Training Institute.

Amin, H., Ghazali, M.F. and Supinah, R. (2010) Determinants of Qardhul Hassan financing acceptance among Malaysian bank customers: An empirical analysis. International Journal of

Business and Society 11(1): 1-16.

Arnould, E., Price, L. and Zikhan, G. (2004) Consumers, 2nd edn.NY: McGraw- Hill.

Aris, N.A., Othman, R., Azli, R.M., Sahri, M., Razak, D.A. and Rahman, Z.A. (2013) Islamic banking products: Regulations, issues and challenges. Journal of Applied Business Research 29(4): 1145-1156.

Ashraf, S., Robson, J. and Sekhon, Y. (2015) Consumer trust and confidence in the compliance of Islamic banks. Journal of Financial Services Marketing 20(2): 133-144.

Asian Development Bank and Islamic Finance Services Board (2015) Islamic Finance for Asia: Development, Prospects, and Inclusive Growth. Asian Development Bank and Islamic Finance Services Board, May 2015.

Billah, M.M.s. (2007) 24 Islamic banking and the growth of takaful. Handbook of Islamic Banking 401.

Bobokhonov, S. and Brito, P.Q. (2015) In travel, discover, marketing. In: K.S. Fam and P.Q. Brito (eds.) 5th Proceedings of MAGScholar Global Business, Marketing and Tourism

Conference. pp 17-25.

Budiman, S. (2012) Analysis of consumer attitudes to purchase intentions of counterfeiting bag product in Indonesia. International Journal of Management, Economics and Social Sciences 1(1): 1-12.

Chowdhury, S.A. (2015) Islamic banking: Current state and future prospects. The Financial Express.

Chowdhury, S.A. (2015a) The current state of the Islamic banking industry in Bangladesh. Islamic Finance News.

Dahari, Z., Abduh, M. and Fam, K.S. (2015) Measuring service quality in Islamic banking: Importanceperformance analysis approach. Asian Journal of Business Research 5(1): 15-28.

Delener, N. (1990) An examination of the religious influences as predictors of consumer innovativeness. Journal of Midwest Marketing 5(167-178).

Dusuki, A.W. and Abdullah, N.I. (2007) Why do Malaysian customers patronise Islamic banks? International Journal of Bank Marketing 25(3): 142-160.

Essoo, N. and Dibb, S. (2004) Religious influences on shopping behaviour: An exploratory study. Journal of Marketing Management 7(8): 683.

Fam, K.S., Waller, D.S. and Erdogan, B.Z. (2004) The Influence of religion on attitude towards advertising of controversial products. European Journal of Marketing 38(5-6): 537-555.

Gait, A. and Worthington, A. (2008) An empirical survey of individual customers, business firm and financial institution attitudes towards Islamic methods of finance. International Journal of Social Economics 35(11): 783808.

Gait, A.H. and Worthington, A. (2009) A Primer on Islamic Finance: Definitions, Sources, Principles and Methods. Australia: Department of Accounting, Finance and Economics, Griffith University.

Gorsuch, R.L. and Smith, C.S. (1983) Attributions of responsibility to god: An interaction of religious beliefs and outcomes. Journal for the Scientific Study of Religion 22(4): 340-352.

Hassan, K. and Mahlknecht, M. (2011) Islamic Capital Markets: Products and Strategies, Volume 609. John Wiley \& Sons.

Hirschman, E.C (ed.) (1983) Religious Affiliation and Consumption Process: An Initial Paradigm. Greenwich, CT: JAI Press. 
Hong, J.K. and Lee, Y.I. (2014) Bancassurance in East Asia: Cultural impact on customers' cross-buying behaviour. Journal of Financial Services Marketing 19(3): 234-247.

Hussein, K. (2010) Bank-level stability factors and consumer confidence - A comparative study of Islamic and conventional banks' product mix. Journal of Financial Services Marketing 15(3): 259-270.

IFSB (2013) Islamic Financial Services Industry Stability Report: Islamic Financial Services Board.

IFSB (2015) Prospects and Challenges in the Development of Islamic Finance for Bangladesh: Islamic Financial Services Board.

Ilyas, S. (1992) Dimensions of Muslim Religiosity: Measurement Considerations. Islamabad, Pakistan: International Institute of Islamic Thought.

Karbhari, Y., Naser, K. and Shahin, Z. (2004) Problems and challenges facing the Islamic banking system in the West: The case of the UK. Thunderbird International Business Review 46(5): 521-543.

Khan, M.S.N., Hassan, M.K. and Shahid, A.I. (2007) Banking behaviour of Islamic bank customers in Bangladesh. Journal of Islamic Economics, Banking and Finance 3(2): 159-194.

Kotler, P., Brown, L., Adam, S. and Armstrong, G. (2004) Marketing. NSW: Pearson Education Australia.

La Barbera, P. (1987) Consumer behaviour and born again Christianity. Research in Consumer Behaviour 2: 193-222.

Laroche, M., Kim, C. and Zhou, L. (1996) Brand familiarity and confidence as determinants of purchase intention: An empirical test in a multiple brand context. Journal of Business Research 37(2): 115-120.

Loo, M. (2010) Attitudes and perceptions towards Islamic banking among Muslims and non-Muslims in Malaysia: Implications for marketing to baby boomers and X-generation. International Journal of Arts and Sciences 3(13): 453-485.

Mamun, D.M.Z. (2011) Prospects and Problems of Islamic Banking from Bank's Perspective: A Study of Bangladesh. Paper presented at the 8th International Conference on Islamic Economics and Finance, Qatar, Doha.Marinov, M. (ed.) (2007) Marketing in the Emerging Markets of Islamic Countries. Palgrave Macmillan. Masry, A.A., Debes, A. and Baradie, M.E. (2015) Islamic and commercial banking systems: A theoretical comparison. Asian Journal of Business Research (special issue).

Matzler, K. and Waiguny, M. (2005) Consequences of customer confusion in online hotel booking. Information and Communication Technologies in Tourism 306-317.

Mejia, A.L., Aljabrin, S., Awad, R., Norat, M. and Song, I. (2014) Regulation and supervision of Islamic banks, IMF Working Paper WP/14/219, December.

Metwally, M. (1996) Attitudes of Muslims towards Islamic banks in a dual-banking system. American Journal of Islamic Finance 6:11-17.

Mukhtar, A. and Butt, M.M. (2012) Intention to choose Halal products : The role of religiosity. Journal of Islamic Marketing 3(2): 108-120.

Osman, I., Ali, H., Zainuddin, A., Rashid, W.E.W. and Jusoff, K. (2009) Customers satisfaction in Malaysian Islamic banking. International Journal of Economics and Finance 1(1): P197.

Porter, M.E. and Schwab, K. (2009) The Global Competitiveness Report (2008-2009): World Economic Forum.

Ramayah, T. and Mohd, S.N. (2006) Intention to use mobile PC among MBA students: Implications for technology integration in the learning curriculum. UNITAR E-Journal 1(2): 1-10.

Rani, N.S.M. (2015) Consumer attitudes and purchase intentions toward Islamic banks: The influence of religiosity. International Journal of Bank Marketing 33(2): 143-161.

Razzaque, M.A. and Chaudhry, S.N. (2013) Religiosity and Muslim consumers' decision-making process in a non-Muslim society. Journal of Islamic Marketing 4(2): 198-217.

Redzuan, H., Rahman, Z.A. and Aidid, S. (2009) Economic determinants of family takaful consumption: Evidence from Malaysia. International Review of Business Research Papers 5(5):193-211.

Rehman, A. and Shabbir, M.S. (2010) The relationship between religiosity and new product adoption. Journal of Islamic Marketing 1(1): 6-69.

Saaty, A.S. and Ansari, Z.A. (2008) Takaful - An Islamic Way of Insurance: Developments, Growth, Challenges and Issues. King Abdulaziz University.

Sadiq, K. and Black, A. (2012) Embracing sharia-compliant products through regulatory amendment to achieve parity of treatment. Sydney Law Review 34: 189. 
Shukor, S.A. and Jamal, A. (2013) Developing scales for measuring religiosity in the context of consumer research. Middle-East Journal of Scientific Research (Research in Contemporary Islamic Finance and Wealth Management) 13: 69-74.

Siddiqui, S.A. and Athemy, A. (2008) Resolving controversial issues and setting goals for Islamic insurance: An evaluation of takaful companies of Brunei. Journal of Islamic Economics, Banking and Finance 3(2): 129-158.

Soesilowati, E.S. (2010) Behaviour of Muslims in Consuming Halal foods: Case of Bantenese Muslim. Paper presented at the Sharia Economics Research Day, Widya Graha Lipi.

Sood, J. and Nasu, Y. (1995) Religiosity and nationality: An exploratory study of their effect on consumer behavior in Japan and the United States. Journal of Business Research 34(1): 1-9.

Sulaiman, M. (2003) The influence of riba and zakat on Islamic accounting. Indonesia Management and Accounting Review 2(2): 149-167.

Sun, S., Goh, T., Fam, K.S. and Xue, Y. (2009) The influence of religion on Islamic mobile phone banking services adoption. Journal of Islamic Marketing 3(1): 81-98.

Taib, F.M., Ramayah, T. and Razak, D.A. (2008) Factors influencing intention to use diminishing partnership home financing. International Journal of Islamic and Middle Eastern Finance and Management 1(3): 235-248.

Tamimi, H.A.H.A., Lafi, A.S. and Uddin, M.H. (2009) Bank image in the UAE: Comparing Islamic and conventional

banks. Journal of Financial Services Marketing 14(3): 232-244. Ullah, S. and Lee, K.H. (2012) Do customers patronize Islamic banks for Shari'a compliance? Journal of Financial Services Marketing 17(3): 206-214.

Vitell, S.J. and Paolillo, J.G.P. (2003) Consumer ethics: The role of religiosity. Journal of Business Ethics 46(2): 151-162.

Warde, I. (2010) Islamic Finance in the Global Economy. Edinburgh University Press.

Youssef, M.A., Kortam, W., Aish, E.A. and El-Bassiouny, N. (2011) Measuring Islamic-driven buyer behavioural implications: A proposed market-minded religiosity scale. Journal of American Science 7(8).

Yun, Z., Verma, S., Pysarchik, D.T., Yu, J. and Chowdhury, S. (2008) Cultural influences on new product adoption of affluent consumers in India. The International Review of Retail, Distribution \& Consumer Research 18(2): 203-220.

Yusof, E.F.E. (2008) Are Islamic Banks in Malaysia really 'Islamic'?. Germany: Munich Personal RePEc Archive.

Yusoff, M.E., Shamsuddin, A.S., Zaidin, N. and Baharun, R.(eds.) (2008) Acceptance of Islamic Finance Product: A Study on Muslim Consumers Attitude in a Non Muslim Country, 1st edn. Johor Darul Ta'zim Malaysia: Penerbit Universiti Teknologi Malaysia.

Zaher, T. and Hassan, M.K. (2001) A comparative literature survey of islamic finance and banking. Financial Markets,Institutions and Instruments 10: 155-199. 


\section{Figure 1: Religiosity-Consumer Behaviour: Conceptual Model}

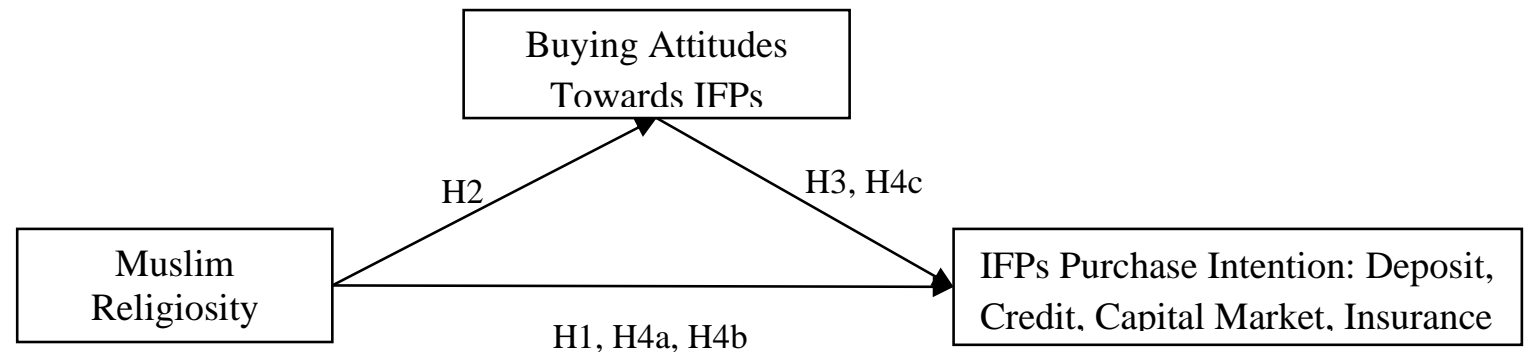

Table 1: The Measurement Model

\begin{tabular}{|c|c|}
\hline Factor Items and Constructs & Loadings* \\
\hline \multicolumn{2}{|l|}{ Religiosity(Second Order Construct): Belief, Practice, Knowledge, Experience, Consequence } \\
\hline \multicolumn{2}{|l|}{ Belief (alpha $=0.82)$} \\
\hline believe that there is no other God but Allah and Mohammad (SWS) is His prophet & 0.69 \\
\hline $\begin{array}{l}\text { believe that there will be the end of time when people will be judged according to how they live } \\
\text { their life in this world }\end{array}$ & 0.69 \\
\hline believe that the Qur'an is the word of Allah, thus its authority is justified & 0.77 \\
\hline believe Hadith is the word of Prophet Mohammad (SWS) and should live life according to this & 0.77 \\
\hline \multicolumn{2}{|l|}{ Practice (alpha $=0.78)$} \\
\hline engage in Dua'a & 0.68 \\
\hline pray five times a day & 0.85 \\
\hline read the Qur'an & 0.67 \\
\hline \multicolumn{2}{|l|}{ Knowledge (alpha $=0.67)$} \\
\hline know the basic and necessary knowledge about my religion & 0.53 \\
\hline always keep myself away from earning through haram (prohibited) means & 0.68 \\
\hline always try to follow Islamic junctions in all matters of my life & 0.68 \\
\hline \multicolumn{2}{|l|}{ Experience (alpha $=0.72)$} \\
\hline have the feeling of being punished by Allah for doing something wrong & 0.63 \\
\hline feel pleasure by seeing others following Islamic teaching & 0.70 \\
\hline religion is especially important because it answers many questions about the meaning of life & 0.70 \\
\hline \multicolumn{2}{|l|}{ Consequence (alpha $=0.78)$} \\
\hline try to avoid any activity that hurts others & 0.74 \\
\hline always avoid humiliating others & 0.85 \\
\hline \multicolumn{2}{|l|}{ Buying Attitude (alpha $=0.85)$} \\
\hline Islamic finance operates in accordance with the principles of Islamic law (or Shariah) & 0.82 \\
\hline Islamic finance follows interest-free principle & 0.92 \\
\hline Islamic finance follows profit and risk sharing principle & 0.68 \\
\hline \multicolumn{2}{|l|}{ Purchase Intention $(a l p h a=0.87)$} \\
\hline eager to learn more about this product related to Islamic Shariah & 0.65 \\
\hline interested in using Islamic financial products and services & 0.90 \\
\hline interested in using Islamic financial products and services in the future & 0.86 \\
\hline definitely recommend Islamic personal financing to others & 0.73 \\
\hline
\end{tabular}

* All factor loadings are significant at $\mathrm{p}<0.001$ 
Table 2: The Structural Model Results

\begin{tabular}{|c|c|c|c|}
\hline Product & Path & Beta & Mediation \\
\hline \multirow{3}{*}{$\begin{array}{l}\text { Overall IFP } \\
\chi 2 / \mathrm{df}=5.05, \text { CFI } 0.933, \\
\text { TLI } .923 \text { and RMSEA } .056\end{array}$} & Religiosity $\rightarrow$ Purchase Intention & $.45 * * *$ & \multirow{3}{*}{$\begin{array}{l}\text { Partial } \\
\text { Mediation }\end{array}$} \\
\hline & Religiosity $\rightarrow$ Buying Attitude & $.53 * * *$ & \\
\hline & Buying attitude $\rightarrow$ Purchase Intention & $.34 * * *$ & \\
\hline \multirow{3}{*}{$\begin{array}{l}\text { Islamic deposit products } \\
\chi 2 / \mathrm{df}=4.80, \text { CFI } 0.938, \\
\text { TLI } .927 \text { and RMSEA } .054\end{array}$} & Religiosity $\rightarrow$ Purchase Intention & $.31 * * *$ & \multirow{3}{*}{$\begin{array}{l}\text { Partial } \\
\text { Mediation }\end{array}$} \\
\hline & Religiosity $\rightarrow$ Buying Attitude & $.53 * * *$ & \\
\hline & Buying attitude $\rightarrow$ Purchase Intention & $.40 * * *$ & \\
\hline \multirow{3}{*}{$\begin{array}{l}\text { Islamic credit products } \\
\chi 2 / \mathrm{df}=4.38, \text { CFI } 0.944, \\
\text { TLI } .934 \text { and RMSEA } .051\end{array}$} & Religiosity $\rightarrow$ Purchase Intention & $.11 * * *$ & \multirow{3}{*}{$\begin{array}{l}\text { Partial } \\
\text { Mediation }\end{array}$} \\
\hline & Religiosity $\rightarrow$ Buying Attitude & $.53 * * *$ & \\
\hline & Buying Attitude $\rightarrow$ Purchase Intention & $.37 * * *$ & \\
\hline \multirow{3}{*}{$\begin{array}{l}\text { Islamic capital market } \\
\text { products }\end{array}$} & Religiosity $\rightarrow$ Purchase Intention & $.17 * * *$ & \multirow{3}{*}{$\begin{array}{l}\text { Partial } \\
\text { Mediation }\end{array}$} \\
\hline & Religiosity $\rightarrow$ Buying Attitude & $.53 * * *$ & \\
\hline & Buying Attitude $\rightarrow$ Purchase Intention & $.31 * * *$ & \\
\hline \multirow{3}{*}{$\begin{array}{l}\text { Islamic insurance } \\
\chi 2 / \mathrm{df}=4.36, \text { CFI } 0.943, \\
\text { TLI } .933 \text { and RMSEA } .051\end{array}$} & Religiosity $\rightarrow$ Purchase Intention & $.04^{N S}$ & \multirow{3}{*}{$\begin{array}{c}\text { Full } \\
\text { Mediation }\end{array}$} \\
\hline & Religiosity $\rightarrow$ Buying Attitude & $.53 * * *$ & \\
\hline & Buying Attitude $\rightarrow$ Purchase Intention & $.13 * * *$ & \\
\hline
\end{tabular}

